\title{
Ammonia and nitrous oxide emissions as affected by nitrification and urease inhibitors
}

\author{
Marta Alfaro $^{1 *}$, Francisco Salazar ${ }^{1}$, Sara Hube $^{1}$, Luis Ramírez, Ma. Soledad Mora ${ }^{2}$ \\ ${ }^{1}$ Instituto de Investigaciones Agropecuarias, INIA Remehue, Ruta 5 Norte, km 8, Osorno, Chile.*malfaro@ \\ inia.cl
}

\begin{abstract}
Soil Nitrogen $(\mathrm{N})$ gaseous losses have environmental and economic implications. Ammonia $\left(\mathrm{NH}_{3}\right)$ volatilization and nitrous oxide $\left(\mathrm{N}_{2} \mathrm{O}\right)$ emissions from a volcanic soil were concurrently quantified using intact lysimeters, after application of the equivalent to $100 \mathrm{~kg} \mathrm{~N} \mathrm{ha}^{-1}$ with and without urease (NBPT) and nitrification (DCD) inhibitor: Urea, Urea+NBPT, Urea+DCD, Dairy slurry and Dairy slurry+DCD. A control treatment (-N) was also included. Treatments were distributed on a randomized block design and evaluated during 28 days. Ammonia was analyzed for $\mathrm{NH}_{4}$ by colorimetry, while $\mathrm{N}_{2} \mathrm{O}$ was estimated by gas chromatography. Total emissions were estimated by addition of daily fluxes, and results were analyzed by ANOVA.

Ammonia was the main N loss, with 35 to $43 \%$ and $5 \%$ to $16 \%$ of the total $\mathrm{N}$ applied in Urea and Dairy slurry $(\mathrm{P}<0.01)$, respectively, with and without inhibitors $(\mathrm{P}>0.05)$. The use of DCD reduced $\mathrm{N}_{2} \mathrm{O}$ emissions by 44 and $8 \%$ in the same treatments, respectively $(\mathrm{P}<0.05)$. Results suggest that DCD has a potential as a mitigation option in grassland volcanic soils reducing $\mathrm{N}_{2} \mathrm{O}$ losses. The use of NBPT did not reduce $\mathrm{NH}_{3}$ losses and $\mathrm{N}_{2} \mathrm{O}$ emissions when applied with urea. Concurrent $\mathrm{N}$ gasses losses from soil showed that indirect $\mathrm{N}_{2} \mathrm{O}$ losses following $\mathrm{NH}_{3}$ volatilization might be more relevant in volcanic soils than direct $\mathrm{N}_{2} \mathrm{O}$ losses.
\end{abstract}

Keywords: Ammonia volatilization, nitrous oxide emissions, NBPT, DCD, Ultisol. 


\section{Introduction}

Ammonia $\left(\mathrm{NH}_{3}\right)$ and nitrous oxide $\left(\mathrm{N}_{2} \mathrm{O}\right)$ are the most important gaseous losses generated by agriculture. Ammonia volatilization influence the formation of acid rain, acid particulate matter, and smelly odors (Luo et al. 2007), and is also indirectly linked to $\mathrm{N}_{2} \mathrm{O}$ and global warming (Erisman et al. 2007); $\mathrm{N}_{2} \mathrm{O}$ is a potent greenhouse gas (GHG) and contributes to the depletion of the ozone layer (IPCC, 2006).

The use of urease (UI) and nitrification inhibitors (NI) has been tested worldwide in grasslands and crops, using fertilizers or organic amendments (e.g. animal manures) on soils, as mitigation option (e.g. Luo et al. 2010; Forrestal et al. 2016). While UI slow urea hydrolysis and reduce the accumulation and volatilization of $\mathrm{NH}_{3}$ (Tomar et al. 1985), NI inhibit the first stage of nitrification, the oxidation of $\mathrm{NH}_{4}+$ to $\mathrm{NO}_{2}-$ by action on the Nitrosomonas sp., which prolongs the $\mathrm{NH}_{4}+$ form in the soil and reduces $\mathrm{N}_{2} \mathrm{O}$ emissions and $\mathrm{NO}_{3}$ - leaching (e.g. Di and Cameron, 2006; Hatch et al. 2005). Studies by Rao and Puttanna (1987) showed that the use of NI can also lead to $\mathrm{N}$ loss through $\mathrm{NH}_{3}$ volatization. This suggests that the action of $\mathrm{NI}$ is conditioned by edapho-climatic factors.

Of the UI globally studied, the most used is N-(n-butyl) thiophosphoric triamide (NBPT). Of the NI, dicyandiamide (DCD), has become the most widely used for its efficient inhibition of nitrification (Trenkel, 1997). However, various studies have indicated that DCD's efficacy at reducing $\mathrm{N}$ loss from $\mathrm{N}_{2} \mathrm{O}$ emissions and $\mathrm{NO}_{3}$ - leaching is variable (e.g. Davies and Williams, 1995, Cahalan et al., 2010). Additionally, DCD has been shown to be strongly affected by soil type, which could be related to soil organic matter content and its microbiological activity (Cahalan et al. 2015).

Soils of Southern Chile have high organic matter (OM) concentration (c. $>10 \%$ to $50 \%$ ), and recent studies have shown that $\mathrm{NH}_{3}$ volatilization would be the main pathway for $\mathrm{N}$ losses in these soils (Salazar et al. 2012a, 2014), with a low contribution of $\mathrm{N}_{2} \mathrm{O}$ (Vistoso et al. 2012; Hube et al. 2017), low $\mathrm{N}$ leaching (Salazar et al., 2012b), and also low nutrient losses following dairy slurry application (Huertas et al., 2016). However, there is little information on the use of nitrogen $(\mathrm{N})$ inhibitors in Chilean volcanic grassland soils, and lack of studies with concurrent measurements of both gases, which would contribute to determine the 'swapping effect' occurring between them. The study aimed to evaluate simultaneous gaseous $\left(\mathrm{NH}_{3}\right.$ and $\left.\mathrm{N}_{2} \mathrm{O}\right)$ losses following the application of urea and dairy slurry, alone or in combination with $\mathrm{N}$ inhibitors in a volcanic grassland soil.

\section{Material and Methods}

Intact soil cores $(0-15 \mathrm{~cm})$ were collected in small PVC lysimeters for gas measurements $(9.7 \mathrm{~cm}$ internal diameter, $20.0 \mathrm{~cm}$ height). The soil was collected at a grassland site from an Ultisols (Typic Hapludult, Soil Survey Staff, 2014), at San Juan de la Costa, Los Lagos Region, Southern Chile ( $\left.39^{\circ} \mathrm{S} ; 73^{\circ} \mathrm{W}\right)$, having a clay texture, more than 1 depth, $15.6 \% \pm 0.82 \mathrm{OM}$ concentration, water $\mathrm{pH}$ of $5.7 \pm 0.03$, and a bulk density of $0.9 \pm 0.01 \mathrm{~g} \mathrm{~cm}^{-3}$. The soil had no $\mathrm{N}$ application in the year prior to the sampling.

Five $\mathrm{N}$ treatments (equivalent rate to $100 \mathrm{~kg}$ total $\mathrm{N} \mathrm{ha}^{-1}$ ) were tested: Urea, Urea+NBPT (N-(n-butyl) thiophosphoric triamide the source of NBPT was Agrotain, (Koch Agronomic Services, Wichita, Kansas, USA); Urea+DCD (Dicyandiamide, Alfa Aesar, USA); Dairy slurry; and Dairy slurry+DCD. Also, a Control $(\mathrm{N}-0)$ treatment was included. Fertilizer granules and dairy slurry were broadcast onto the grass surface and $\mathrm{N}$ inhibitors solutions were surface sprayed immediately after fertilizer granules or dairy 
slurry applications, at recommended rates $(1.25 \mathrm{~g}$ Agrotain $\mathrm{kg}^{-1} \mathrm{~N}$ applied, and $10 \mathrm{~kg} \mathrm{DCD} \mathrm{ha}{ }^{-1}$, respectively). Treatments were distributed on a randomized block design $(\mathrm{n}=4)$ and evaluated under controlled conditions $\left(80 \%\right.$ water field pore space-WFPS, $\left.20^{\circ} \mathrm{C}\right)$ for 28 days. Soil moisture was maintained constant by gravimetric water balance adding deionized water over time, when required. Fresh dairy slurry was collected from the experimental farm at Remehue Research Centre (Osorno, Chile) for each experiment and separate samples of slurry for each replicate $(n=4)$ were collected and chemically analyzed (Table 1).

Table 1. General characteristics ( \pm standard error of the mean) of dairy slurry used in the experiment $(n=4)$.

\begin{tabular}{ccr}
\hline Parameter & Unit & \multicolumn{1}{c}{ Dairy slurry } \\
\hline Dry matter & $\left(\mathrm{g} \mathrm{100} \mathrm{g}^{-1^{* *}}\right)$ & $3.1 \pm 0.24$ \\
Organic matter & $\left({\left.\mathrm{g} 100 \mathrm{~g}^{-1^{*}}\right)}^{\circ}\right.$ & $63.4 \pm 0.66$ \\
$\mathrm{pH} \mathrm{H} \mathrm{H}_{2} \mathrm{O}$ & $\left(\mathrm{u}^{* *}\right)$ & $7.6 \pm 0.02$ \\
$\mathrm{C}$ & $\left({\left.\mathrm{g} 100 \mathrm{~g}^{-1^{*}}\right)}^{-}\right.$ & $35.2 \pm 0.35$ \\
Total N & $\left(\mathrm{kg} \mathrm{t}^{-1^{* *}}\right)$ & $1.21 \pm 0.003$ \\
$\mathrm{~N}-\mathrm{NH}_{4}$ & $\left(\mathrm{mg} \mathrm{kg}^{-1^{* * *}}\right)$ & $0.34 \pm 0.003$ \\
$\mathrm{~N}^{-N_{3}}$ & $\left(\mathrm{mg} \mathrm{kg}^{-1^{* *}}\right)$ & $0.01 \pm 0.003$ \\
\hline
\end{tabular}

*Dry weight basis; **fresh weight basis

The dynamic chambers using for measuring $\mathrm{NH}_{3}$ were similar to those used in previous studies (e.g. Chadwick et al., 2001), incorporating a transparent PVC lid on the top of each to allow plants photosynthesis. This lid had two inlets and two outlets that were connected to a vacuum pump with a constant air flow of $4 \mathrm{~L} \mathrm{~min}^{-}$ ${ }^{1}$. These systems have the potential to over-estimate ammonia losses, nevertheless the system provides a good comparison of treatment/inhibitor effects. The air was scrubbed clean of $\mathrm{NH}_{3}$ by bubbling through $100 \mathrm{~mL}$ of $0.02 \mathrm{M}$ orthophosphoric acid, and then passed through a similar trap to capture $\mathrm{NH}_{3}$. The acid traps were changed at $6 \mathrm{~h}$ and then every $24 \mathrm{~h}$ for the first week, and every 2-3 days until day 28 . Aliquots from the outlet $\mathrm{NH}_{3}$ traps were stored $\left(3-4^{\circ} \mathrm{C}\right)$ until analyzed for ammonium using automated colorimetry (SKALAR, SA 4000, Breda, The Netherlands). Ammonia loss was calculated as the product of the total airflow and the difference between $\mathrm{NH}_{3}$ concentrations in the air leaving and entering the chamber.
Nitrous oxide emissions were quantified using an adaptation of the closed static chamber technique (Saggar et al. 2004) setting up at the top of the lysimeters, when $\mathrm{NH}_{3}$ sampling was done. Air samples $(30 \mathrm{~mL})$ were taken at 0,20 and 40 min of deployment in $22 \mathrm{~mL}$ glass vials. Air samples were taken before the fertilizer addition and 1, 3, 5, 9, 14, 21 and 28 days afterward. The concentration of $\mathrm{N}_{2} \mathrm{O}$ in the gas samples was determined using a Gas Chromatograph (Perkin Elmer ${ }^{\mathbb{B}}$ Precisely, Clarus 600 Model, Shelton, USA) fitted with a $63 \mathrm{Ni}$ electron capture detector (ECD). The $\mathrm{N}_{2} \mathrm{O}$ fluxes were calculated using the equations described in Saggar et al. (2004). Indirect $\mathrm{N}_{2} \mathrm{O}$ emissions from $\mathrm{NH}_{3}$ volatilization were estimated as $1 \%$ of total $\mathrm{N}$ losses as $\mathrm{NH}_{3}$, as suggested by the methodology provided by the Intergovernmental Panel for Climate Change (IPCC, 2006). Fluxes and cumulative $\mathrm{NH}_{3}$ and $\mathrm{N}_{2} \mathrm{O}$ emissions were analyzed by ANOVA using Genstat 12.2. Means comparison was made using a Least Significant Difference Test (LSD). 


\section{Results}

Most of $\mathrm{NH}_{3}$ and $\mathrm{N}_{2} \mathrm{O}$ losses were concentrated in the first six days of the experiment. In this period, between $64 \%$ (Dairy slurry+DCD) to $92 \%$ (Urea) of $\mathrm{N}^{-\mathrm{NH}_{3}}$ losses, and between $31 \%$ (Urea) to $58 \%$ (Dairy slurry) of $\mathrm{N}_{-} \mathrm{N}_{2} \mathrm{O}$ losses occurred (Figure 1).

Ammonia emission rates were greater, for all the treatments, than those observed for $\mathrm{N}_{2} \mathrm{O}$, reaching up to $73.1 \mathrm{mg} \mathrm{N} \mathrm{N}-\mathrm{NH}_{3} \mathrm{~m}^{-2} \mathrm{~h}^{-1}$ with urea $(\mathrm{P}<0.01)$, and higher than those treated with dairy slurry. Fluxes of $\mathrm{N}_{2} \mathrm{O}$ were higher in the dairy slurry treatments, with and without DCD compared to urea and control treatments, where the highest emission rates were observed on the first five days following the application of Dairy slurry treatment (Figure 1). The pattern of ammonia emission was similar for slurry treatments, where high peaks were observed immediately after dairy slurry application and dropped quickly up to day two were emissions rates were similar to the control treatment. Urea treatments shows a different emission pattern compared to dairy slurry treatments, with low losses immediately following urea application to soil and with high rates from day one to six.

Cumulative $\mathrm{NH}_{3}$ emissions after urea application varied from $3.5 \pm 0.25$ to $4.3 \pm 0.25 \mathrm{~g} \mathrm{~N}^{-N_{3}} \mathrm{~m}^{-2}$, which was equivalent to c. $35 \%$ to $43 \%$ of the total $\mathrm{N}$ applied (with and without $\mathrm{N}$ inhibitors) being much higher than those observed for dairy slurry and control $(\mathrm{N}-0)$ treatments, respectively $(\mathrm{P}<0.01$; Table 2$)$. Cumulative $\mathrm{N}_{2} \mathrm{O}$ emissions were higher in the Dairy slurry treatment, with and without DCD (54.2 \pm 9.85 $\mathrm{mg} \mathrm{N}-\mathrm{N}_{2} \mathrm{O} \mathrm{m}^{-2}$, on average; Table 2). The use of DCD reduced $\mathrm{N}_{2} \mathrm{O}$ emissions by $44 \%$ and $8 \%$ when used with Urea and Dairy slurry, respectively. The use of both inhibitors did not change the pattern of $\mathrm{NH}_{3}$ or $\mathrm{N}_{2} \mathrm{O}$ emissions in relation to the same treatment with no inhibitors addition $(\mathrm{P}>0.05$; Figure 1$)$.

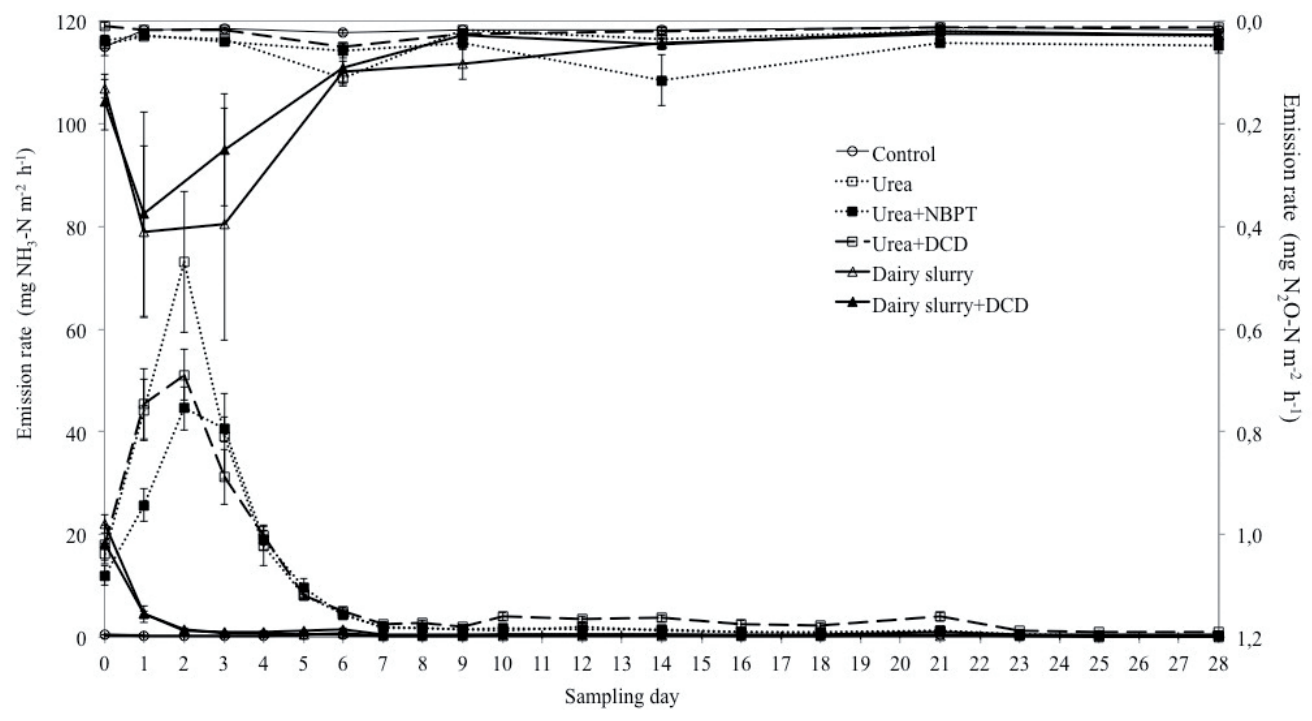

Figure 1. Average $\mathrm{N}-\mathrm{NH}^{3}$ (left axis) and $\mathrm{N}-\mathrm{N}_{2} \mathrm{O}$ (right axis) emission rates per treatment $\left(\mathrm{mg} \mathrm{N} \mathrm{m}^{-2} \mathrm{~h}^{-1}\right)$. Errors bars represent the standard error of the mean from four replications. 
Table 2. Cumulative $\mathrm{N}$ gaseous losses $\left(\mathrm{mg} \mathrm{N} \mathrm{m}^{-2}\right)$ ( $\left(\right.$ standard error of the mean) and $\mathrm{N}-\mathrm{NH}_{3} / \mathrm{N}_{-}-\mathrm{N}_{2} \mathrm{O}$ losses ratio for data reported in the experiment $(n=4)$.

\begin{tabular}{|c|c|c|c|}
\hline & \multicolumn{2}{|c|}{ Cumulative $\mathrm{N}$ losses $\left(\mathrm{mg} \mathrm{m}^{-2}\right)$} & Ratio \\
\hline Treatments & $\mathrm{N}-\mathrm{NH}_{3} *$ & $\mathrm{~N}-\mathrm{N}_{2} \mathrm{O}^{* *}$ & $\mathrm{~N}-\mathrm{NH}_{3} / \mathrm{N}-\mathrm{N}_{2} \mathrm{O}$ \\
\hline Control & $151.4 \pm 31.40 \mathrm{c}$ & $13.0 \pm 2.05 \mathrm{c}$ & 11.6 \\
\hline Urea & $4,293.6 \pm 245.88 \mathrm{a}$ & $26.3 \pm 3.44 \mathrm{~b}$ & 163.5 \\
\hline Urea+NBPT & $3,534.7 \pm 97.25 \mathrm{a}$ & $32.3 \pm 5.41 \mathrm{~b}$ & 109.4 \\
\hline Urea+DCD & $4,216.9 \pm 260.50 \mathrm{a}$ & $13.9 \pm 1.55 \mathrm{c}$ & 303.7 \\
\hline Dairy slurry & $350.6 \pm 47.63 b$ & $54.36 \pm 12.60 \mathrm{a}$ & 6.4 \\
\hline Dairy slurry+DCD & $481.3 \pm 55.37 b$ & $54.06 \pm 17.15 \mathrm{a}$ & 8.9 \\
\hline
\end{tabular}

\section{Discussion}

Volatilization of $\mathrm{NH}_{3}$ was the main pathway of $\mathrm{N}$ loss in this volcanic soil, in agreement with previous results (Salazar et al. 2014), with loss rates peaking within one to three days after dairy slurry or urea, respectively, for surface applications to grasslands (Figure 1). In addition, most of the $\mathrm{N}_{2} \mathrm{O}$ loss occurred within six days following application. Therefore, mitigation options for grasslands, especially for $\mathrm{NH}_{3}$, should be focusing in early periods after surface $\mathrm{N}$ application.

Ammonia losses were much higher on urea treatments compared to the dairy slurry or control treatments. The low $\mathrm{NH}_{3}$ loss observed when using dairy slurry, based on total $\mathrm{N}$, could be associated to its low $\mathrm{N}^{-\mathrm{NH}_{3}}$ content $(25.7 \% \pm 1.0 \%$ of the total $\mathrm{N})$, which is common from grazing dairy systems (Salazar et al., 2007) and due the diluted composition of the dairy slurry, which can then rapidly infiltrate into the soil, reducing the potential for $\mathrm{NH}_{3}$ loss (Smith and Chambers, 1995). Additionally, the high soil moisture conditions prevalent during the experiment could have further reduced the potential for $\mathrm{NH}_{3}$ loss.
The use of DCD reduced $\mathrm{N}_{2} \mathrm{O}$ emissions when used with Urea and Dairy slurry. This agrees with previous data from the use of DCD in grassland soils of New Zealand (Di and Cameron 2006; Saggar et al. 2009), although these studies results were higher than those reported after an autumn $\mathrm{N}$ fertilizer addition on an Andisol of Southern Chile (Vistoso et al. 2012). This was probably because the current experiment was carried out at $80 \%$ WFPS, providing anaerobic conditions beneficial for denitrification. Additionally, the efficacy of DCD has been shown to be affected by soil type (Cahalan et al. 2015) with higher degradation rates of DCD in soils with higher organic matter concentrations, such as that used in the current experiment $(15.6 \% \pm 0.86)$.

Ammonia volatilization was 164 and six times greater than losses as $\mathrm{N}_{2} \mathrm{O}$ for Urea and Dairy slurry, respectively (Table 1). Moreover, $\mathrm{NH}_{3}$ has been recognized as $\mathrm{N}_{2} \mathrm{O}$ precursor (Erisman et al. 2007), so that in the current experiment indirect $\mathrm{N}_{2} \mathrm{O}$ emissions from $\mathrm{NH}_{3}$ volatilization estimated according to the Intergovernmental Panel for Climate Change (IPCC, 2006), varied between 4 and $43 \mathrm{mg} \mathrm{N}^{-\mathrm{N}_{2}} \mathrm{O} \mathrm{m}^{-2}$, being equivalent to $6 \%$ (Dairy slurry) to $75 \%$ (Urea+DCD) of the total 
$\mathrm{N}-\mathrm{N}_{2} \mathrm{O}$ emissions, considering both direct and estimated indirect $\mathrm{N}_{-} \mathrm{N}_{2} \mathrm{O}$ losses. These results suggest that indirect $\mathrm{N}_{2} \mathrm{O}$ losses following $\mathrm{NH}_{3}$ volatilization might be more relevant in volcanic soils than direct $\mathrm{N}_{2} \mathrm{O}$ losses. Field studies using micrometeorological integrated horizontal flux mass balance (Denmead et al. 1977) and the small wind tunnels methods (Lockyer 1984) on permanent grasslands in Southern Chile have shown that $\mathrm{NH}_{3}$ volatilization ranged from 1.4 to $26.7 \%$ of the $\mathrm{N}$ applied as urea, being the main pathway for $\mathrm{N}$ losses on grassland soils (Salazar et al. 2012a; Salazar et al. 2014), grazing systems (Nuñez et al. 2010), and from livestock production systems (Muñoz et al., 2016), probably contributing more to GHG emissions from grassland soils than direct $\mathrm{N}_{2} \mathrm{O}$ emissions. Studies in this area have also shown a low contribution of $\mathrm{N}$ losses by nitrate leaching (Salazar et al. 2012b) and $\mathrm{N}_{2} \mathrm{O}$ (Vistoso et al. 2012; Hube et al. 2017).

The inhibitor DCD could be adopted as a mitigation option in soils to reduce $\mathrm{N}_{2} \mathrm{O}$ losses when using urea or dairy slurry in volcanic soils, in agreement with studies reported worldwide (e.g. Saggar et al. 2009). However, according to a meta-analysis carried out by Kim et al. (2012) nitrification inhibitors could have a variable effect on $\mathrm{NH}_{3}$ losses following urea application, with most studies reporting a significant increase on $\mathrm{NH}_{3}$ loss.

The use of NBPT should be further evaluated, with no $\mathrm{N}$ loss reduction in this study but reported reductions of $\mathrm{N}$ losses between c. $60-80 \%$ when using urea+NBPT compared to urea in field studies carried out in the same area (Salazar et al. 2014) and in grasslands experiments in Ireland (Forrestal et al. 2016). Further evaluations should consider the analysis of NBPT soil degradation or inactivation in soils with high organic matter concentrations. Additionally, meta-analysis and field experiments indicate that the use of NBPT, although with a minor effect on emissions, could benefit nitrogen use efficiency in crops (Akiyama et al. 2010;
Hube et al. 2017), that effect could have been missed under the controlled conditions and the short evaluation period of the current experiment.

\section{Conclusions}

Ammonia volatilization was the main $\mathrm{N}$ loss, with 35 to $43 \%$ and $5 \%$ to $16 \%$ of the total and available $\mathrm{N}$ applied in the Urea and Dairy slurry treatments, with and without inhibitors, respectively. The use of DCD reduced $\mathrm{N}_{2} \mathrm{O}$ emissions by 44 and $8 \%$ when used with Urea and Dairy slurry, respectively. The use of NBPT did not significantly reduce $\mathrm{NH}_{3}$ losses or $\mathrm{N}_{2} \mathrm{O}$ emissions from urea treatments. Results on concurrent $\mathrm{N}$ gasses losses from soil, showed that indirect $\mathrm{N}_{2} \mathrm{O}$ losses following $\mathrm{NH}_{3}$ volatilization might be more relevant in volcanic soils than direct $\mathrm{N}_{2} \mathrm{O}$ losses.

The simultaneous study of both gases provided a comprehensive analysis of $\mathrm{N}$ losses to air in a volcanic soil, including an assessment of the pollution swapping effect. Thus, indirect $\mathrm{N}_{2} \mathrm{O}$ losses following $\mathrm{NH}_{3}$ volatilization can be highly relevant to understand $\mathrm{N}$ fate in volcanic soils.

\section{Acknowledgements}

Thanks to Fondo Nacional de Desarrollo Científico y Tecnológico de Chile, grants 1130718 and 1151078. Thank you to Dr. Tom Misselbrook from Rothamsted Research North Wyke (United Kingdom), and Dr. Surinder Saggar and Peter Berben from Landcare Research (New Zealand). 


\section{References}

Akiyama, H., Yan, X., Yagi, K. 2010. Evaluation of effectiveness of enhanced-efficiency fertilizers as mitigation options for $\mathrm{N}_{2} \mathrm{O}$ and $\mathrm{NO}$ emissions from agricultural soils: meta-analysis. Global Change Biology 16, 1837-1846.

Cahalan, E., Minet, E., Enfors, M., Mueller, C., Devaney, D., Forrestal, P.J., Richards, K.G. 2015. The effect of precipitation and application rate on DCD persistence and efficiency in two Irish grassland soils. Soil Use and Management 31, 367-374.

Chadwick, D.R., Martínez, J., Marol, C., Béline, F. 2001. Nitrogen transformations and ammonia loss following injection and surface application of pig slurry: a laboratory experiment using slurry labelled with $15 \mathrm{~N}$-ammonium. Journal of Agricultural Science, Cambridge 136, 231-240.

Davies D.M., Williams P.J. 1995. The effect of the nitrification inhibitor dicyandiamide on nitrate leaching and ammonia volatilization, a UK nitrate sensitive areas perspective. Journal of Environmental Management 45,263-272.

Denmead, O., Simpson, J., Freney, J. 1977. Direct field measurement of ammonia emission after injection of anhydrous ammonia. Soil Science Society of America Journal 41, 1001-1004.

Di, H.J., Cameron, K.C. 2006. Nitrous oxide emissions from two dairy pasture soils as affected by different rates of a fine particle suspension nitrification inhibitor, dicyandiamide. Biology and Fertility of Soils 42, 472-480.

Erisman, J., Bleeker, A., Galloway, J., Sutton, M. 2007. Reduced nitrogen in ecology and the environment. Environmental Pollution 150,140-149.
Forrestal, P.J., Harty, M., Carolan, R., Lanigan, G.J., Watson, C.J., Laughlin, R.J., McNeill, G., Chambers, B.J., Richards, K.G. 2016. Ammonia emissions from urea, stabilized urea and calcium ammonium nitrate; insight into loss abatement in temperate grassland. Soil Use and Management $32,92-100$.

Hube, S., Alfaro, M., Scheers, C., Brunk, C., Ramírez, L., Rowlings, D., Grace, P. 2017. Effect of nitrification and urease inhibitors on nitrous oxide and methane emissions from an oat crop in a volcanic ash soil. Agriculture, Ecosystem and Environment $238,46-54$.

Huertas, J, Cuevas, J.G., Paulino, L., Salazar, F., Arumí, J.L., Dörner, J. 2016. Dairy slurry application to grasslands and groundwater quality in a volcanic soil. Journal of Soil Science and Plant Nutrition, 16: 745-762.

IPPC, 2006. 2006 IPCC Guidelines for National Greenhouse Gas Inventories, Vol 4, Agriculture, Forestry and Land Use. Prepared by the National Greenhouse Inventoried Programme. Eggleston, H.S., Buendia, L., Miwa, K., Ngara, T., Tanabe, K. (eds). IGES, Japan.

Kim, D.G., Saggar, S., Roudier, P. 2012. The effect of nitrification inhibitors on soil ammonia emissions in nitrogen managed soils: a meta-analysis. Nutrient Cycling in Agroecosystems 93, 51-64.

Lockyer, D, 1984. A system for the measurement in the field of losses of ammonia through volatilization. Journal of the Science of Food and Agriculture $35,837-848$.

Luo, C., Zender, C., Bian, H., Metzger, S. 2007. Role of ammonia chemistry and coarse mode aerosols in global climatological inorganic aerosol distributions. Atmospheric Environment 41, 2510-2533. 
Luo, J., de Klein, C.A.M., Ledgard, S.F., Saggar, S. 2010. Management options to reduce nitrous oxide from intensively grazed pasture: a review. Agriculture, Ecosystems and Environment 136, 282-291.

Muñoz, E., Navia, R., Zaror, C., Alfaro, M. 2016. Ammonia emissions from livestock production in Chile: an inventory and uncertainty analysis. Journal of Soil Science and Plant Nutrition 16, 60-75.

Nuñez, R. P., Demanet, R., Alfaro, M., Mora, M.L. 2010. Nitrogen soil budgets in contrasting dairy grazyng systems of Southern Chile, a short-term study. Journal of Soil Science and Plant Nutrition 10, 170-183.

Rao E.V.S. P., Puttanna K. 1987. Nitrification and ammonia volatilization losses from urea and dicyandiamide-treated urea in a sandy loam soil. Plant and Soil 97, 201-206.

Saggar, S., Andrew, R.M., Tate, K.R., Hedley, C.B., Rodda, N.J., Townsend, J.A. 2004. Modelling nitrous oxide emissions from dairy-grazed pastures. Nutrient Cycling in Agroecosystems 68, 243-255.

Saggar, S., Luo, J., Giltrap, D.L., Maddena, M. 2009. Nitrous oxide emissions from temperature grasslands: Processes, measurements, modelling and mitigation, in: Sheldon, A.I., and Barnhart, E.P. (Eds.), Nitrous oxide emissions research progress. Novoa Science Publishers Inc., New York, 66 p.

Salazar, F., Dumont, J., Chadwick, D., Saldaña, R., Santana, M. 2007. Characterization of dairy slurry in Southern Chile farms. Chilean Journal of Agriculture Research 67, 155-162.

Salazar, F., Martínez-Lagos, J., Alfaro, M., Misselbrook, T. 2012a. Ammonia emissions from urea application to permanent pasture on a volcanic soil. Atmospheric Environment 61, 395-399.
Salazar, F., Martínez-Lagos, J., Alfaro, M., Misselbrook, T. 2012b. Low nitrogen leaching losses following a high rate of dairy slurry and urea application to pasture on a volcanic soil in Southern Chile. Agriculture, Ecosystems and Environment 160, 23-28.

Salazar, F., Martínez-Lagos, J., Alfaro, M., Misselbrook, T. 2014. Ammonia volatilization following application of dairy slurry, urea and urea with a urease inhibitor to permanent grassland on a volcanic soil. Atmospheric Environment 95, 591-597.

Smith, K.A., Chambers, B.J. 1995. Muck: from waste to resource. Utilisation: the impacts and implications. Agricultural Engineer 50, 33-38.

Soil Survey Staff. 2014. Keys to Soil Taxonomy. USDA and Natural Resources Conservation Service, Washington, DC, 12th ed. 399p

Tomar J.S., Kirby P.C., Mackenzie A.F. 1985. Fieldevaluation of the effects of a urease inhibitor and crop residues on urea hydrolysis, ammonia volatilization and yield of corn. Canadian Journal of Soil Science 65,777-787.

Trenkel M.E. 1997. Controlled-release and stabilized fertilizer in agriculture. International Fertilizer Industry Association, Paris. 151p.

Vistoso, E., Alfaro, M, Saggar, S., Salazar, F. 2012. Effect of nitrogen Inhibitors on nitrous oxide emissions and pasture growth following an autumn application in a volcanic soil. Chilean Journal of Agricultural Research 72, 133-139. 